\title{
The Provision of the Disabled Facilities in Public Hospitals
}

\author{
Yuhainis Abdul Talib, Nurul Izzati Abdul Ghani ${ }^{2}$, Kharizam Ismail ${ }^{3}$ and Nor'Aini Salleh ${ }^{4}$ \\ 1,2,3,4 Faculty of Architecture, Planning and Surveying, Universiti Teknologi MARA, Seri Iskandar Campus, 32610, Seri Iskandar, Perak, \\ Malaysia
}

\begin{abstract}
The implementation of Person with Disabilities Act 2008 has become an eye opener towards the provision of disabled facilities in all public buildings especially regarding healthcare accessibility. The aim of this research is to analyse the provision of the disabled facilities provided in a public hospital in Perak, Malaysia. To support the research, it was supporting with two objectives that are to identify the designs and requirements of disabled facilities that need to be fulfilled according to Uniform Building By-Laws (UBBL) and other standard regulations and to identify the level of awareness of public on disabled facilities in the public hospital. For the purpose of the research, the observation method has been done towards three (3) selected hospital in Perak and questionnaire survey have been distributed to 96 respondents among the staff and visitors of the hospitals. All the data collected from the questionnaire survey and the checklist using UBBL standard requirement, then analysed using the SPSS V.21. The outcome of the observation indicates that most of the hospitals were provided with the disabled facilities, but there are still some rooms for improvement regarding specifications and the provision itself. In a nutshell, this research helps the management of the hospital together with the public on the importance of the provision of the disabled facilities in public buildings.
\end{abstract}

\section{Introduction}

All hospitals must be user-friendly regardless of the ages, races, gender especially to disabled persons. According to News Straits Times in [10], Mayor Datuk Mat Noh Ahmad said that it is necessary for buildings proposed to be disabled-friendly to get approval under the Persons with Disabilities Act 2008. This act is developed to ensure public beneficial especially to a disabled person.

According to Ibrahim (10), the United Nations estimates that the number of persons with disabilities in Malaysia is about 2.8 million, or 10 per cent of its population of 28 million. However, Social Welfare Department (JKM) statistics, as of August 2010, showed that only 313,685 People with Disabilities (PWD) had registered with the department. This means there are a large amount of disabled people in the country who have not registered with JKM. Islam [6] said that persons with disabilities are usually the nation's largest minority, and they tend to be marginalized in all aspects of life. Many visitors and caregivers who also disabled from poor families were forced to sleep in hospital corridors [8]. In many countries, access for patrons with disabilities to enjoy the facilities in the hospital is less taken into

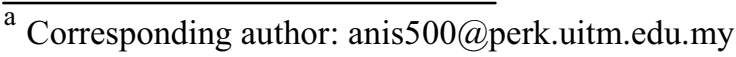

account and sometimes is taken for granted. The process of managing the facilities is more challenging due to the complexity of healthcare buildings [2].

Therefore, this research emphasizes on two objectives:

i. To identify the designs and requirements of disabled facilities that need to be fulfilled according to Uniform Building By-Laws (UBBL) and other standard regulations

ii. To determine the level of awareness of public on disabled facilities in public hospital

\section{Disable facilities in public hospitals}

Disability can be defined as the restrictions of activity by society towards a person where impairments are the characteristics or feature that cause restrictions in conducting the activity that may cause injuries that affect their appearance, communications and functions of the body [9].

The recently published World Report on Disability suggests there are approximately one billion people across the globe with some form of disability, representing around $15 \%$ of the world's population. The trend was a sizeable increase from the last World Health 
Organisation estimate of around 10\% in the 1970s [13]. Besides, the United Nations estimates that the number of persons with disabilities in Malaysia is about 2.8 million, or 10 percent of its population of 28 million [4].

A district hospital typically is the major health care facility in its region, with large numbers of beds for intensive care and long-term care with the provision of primary-level hospital-based services [12]. District hospitals can overcome the territorial imbalance and reduce the difficulties in accessing the health-care system of those towns that are far from metropolitan areas at a reasonable cost [11].

\subsection{Person with Disabilities Act 2008 (Act 685)}

Part III of Act 685 provides that persons with disabilities must be given the right to access and use of public facilities, amenities and services and buildings provided to the public on an equal basis with people without disabilities. As such the Government and the providers of such public facilities, amenities, services and buildings are required to give an appropriate consideration and take necessary measures to ensure that such public facilities, amenities, services and buildings and the improvement of the equipment related is to conform to universal design.

\subsection{Provision of By-laws 34A of the Uniform Building Bylaws (UBBL)}

Bylaws 34A of the Uniform Building Bylaws makes it mandatory for all public buildings to make available facilities for disabled persons. On September 20th, 1990 an amendment was made to the Uniform Building Bylaws (UBBL) at the 35th National Council of Local Government (NCLG). The amendment, introduced section 34A in UBBL, making it compulsory for buildings to provide access to enable disabled persons to get into, out of and within the buildings.

\subsection{Malaysian Standards for Persons with Disability}

Despite all the other standard regulations, Malaysia also has their standard regulations that need to be followed by the designers and management.

a) Malaysian Standard 1183:1990- Code of Practice for Means of Escape for Disabled Persons

Code of Practice for Fire Precautions in the Design and Construction of Buildings (MS 1183) issued by SIRIM in 1990 requiring special standards to be complied with in providing fire precautions in designing public buildings to make it safe for the use of disabled persons especially during a fire.

b) Malaysian Standard 1184:2002, Code of Practice on Access for Disabled Persons to Public Buildings (First Revision)
This MS specifies the basic requirements for elements of buildings and related facilities so as to permit access by Person with Disabilities (PWD). These requirements apply to all buildings that PWDs may use as members of the general public, as visitors or for purposes of employment. By implementation of this standard, all the disabled people can now access to the public buildings. This standard supersedes MS 1184:1991.

c) Malaysian Standard 1331:2003, Code of Practice for Access for Disabled Persons Outside Buildings (First Revision)

This standard supersedes MS 1331:1993. This code revised about the provisions on designing of special facilities outside buildings for disabled people to ensure accessibility and usability by disabled persons. In complying with this Standard, all building plans submitted to the local authorities after the date the Code of Practice is published in the State Gazette, each State must comply with it.

\subsection{Town and Country Planning Act 1976}

The Town and Country Planning Act 1976 though not providing in clear, precise terms the requirement to create accessibility for disabled persons, however, requires planning authorities to ensure that provisions of other related written laws are taken into consideration in the process of approving applications for planning permission.

\subsection{Provision of Disabled Facilities According to the Standard Regulations}

Positive supports encourage them to prove their capabilities while public stereotype and prejudice towards PWD may diminish their self-esteem and confidence to participate in the social and economic mainstream [7]. According to Abdul Rahim [1], a more barrier-free design of facilities need to be constructed as all categories of people can enjoy the facilities. Hence, all the buildings and facilities in Malaysia must be disabled friendly and free from any barriers that can limit the involvement of the disabled person to avoid the disabled people sidelined from the city growth [1]. The statement also supported by Imrie [5] which saying that barrier-free facilities are the mechanism for a disabled person to access into the public building.

\section{Methodology}

According to Creswell [3], the combination of qualitative and quantitative will provide more understanding compared to single approach alone. Hence, to gain the benefit of a mixed method, this study will adopt quantitative method using structured questionnaire survey with recommendation/comment by respondents. While, qualitative method will be done through observation to the facilities provided, observation based on the checklist 
prepared, will be done as a first phase and follow by questionnaire survey as second phase.

The questionnaire survey will be distributed among the staff and visitors of the hospital. Earlier, observation will be done according to the checklist that already been made based on UBBL standard for disable facilities for the hospital building. The checklist will be consists of data regarding the appropriate specification and provision of disabled facilities in the hospital according to the standard regulations by the authorities. From the result of the checklist gathered, the questionnaire will be developed. This is to ensure the validity of the questions.

In this research, the population and sample will be the visitors or staff in three selected public hospital around Perak; Hospital Raja Permaisuri Bainun, Hospital Seri Manjung, and Hospital Kuala Kangsar. Hence, the population of the sample will be determined according to the total number of beds in each hospital as shown in Table 1

Table 1: Number of beds in three selected public hospital

\begin{tabular}{|l|l|}
\hline Hospitals & $\begin{array}{l}\text { No. Of } \\
\text { Beds }\end{array}$ \\
\hline $\begin{array}{l}\text { Hospital Raja Permaisuri Bainun } \\
\text { (HRPB) }\end{array}$ & 990 \\
\hline Hospital Seri Manjung (HSM) & 270 \\
\hline Hospital Kuala Kangsar (HKK) & 136 \\
\hline Total & 1396 \\
\hline
\end{tabular}

From the total of the population above, the number of a sample will be abstracted from the level of a precision table for determining sample size for $\pm 3 \%, \pm 5 \%, \pm 7 \%$, and $\pm 10 \%$ precision levels where confidence level is $95 \%$ and $\mathrm{p}=0.5$ as shown in Table 1 . The total sample that an appropriate for this research is 96 samples according to the precision level $10 \%$.

All the data collected from the questionnaire survey and the observation will be analysed and will be presented in the form of a table. Each of the data will be evaluated and explained in detail. All the data analysed using Statistical Package for Social Sciences (SPSS) V.21 software. The questionnaire survey distributed were returned and answered by the respondents because the method used was face to face and researcher help respondent to answer on the spot. The researcher approached the respondent during recess hour for staff and during visit hour for visitors.

\section{Provision of the disabled facilities provided in public hospital}

Table 1 shows all the result from the observation that has been done to all the three selected hospital in Perak. Based on the list that has been provided, if the facilities follow all the requirements in the list it would be marked with '/'. Facilities that did not follow the list it will be marked with ' $\mathrm{X}$ ', while those facilities that not provided at all will be marked with 'NA'. During the technical visit, all the facilities have been strictly observed to ensure that all the result is valid.

Table 2 Observation result regarding disabled facilities in selected hospital

\begin{tabular}{|c|c|c|c|c|}
\hline 1 & STAIRCASE & & & \\
\hline a) & $\begin{array}{l}\text { Tactile floor located } \\
\text { atleast } 400 \mathrm{~mm} \text { before } \\
\text { the step }\end{array}$ & NA & NA & NA \\
\hline b) & $\begin{array}{l}\text { Continuous handrails } \\
\text { provided }\end{array}$ & / & / & / \\
\hline c) & $\begin{array}{l}\text { Braile inscription at the } \\
\text { handrail }\end{array}$ & NA & NA & NA \\
\hline 2 & RAMP & & & \\
\hline a) & $\begin{array}{l}\text { The ramp is free from } \\
\text { any obstructions and } \\
\text { anti-slip }\end{array}$ & 1 & / & / \\
\hline b) & $\begin{array}{l}\text { The ramp should atleast } \\
1200 \mathrm{~mm} \text { wide }\end{array}$ & / & / & I \\
\hline c) & $\begin{array}{l}\text { There is handrails } \\
\text { provided on both sides }\end{array}$ & NA & / & $\mathrm{X}$ \\
\hline d) & $\begin{array}{l}\text { The ramp should be of } \\
\text { gentle gradient with } \\
\text { landing maximum every } \\
6 \text { metres }\end{array}$ & NA & / & / \\
\hline e) & $\begin{array}{l}\text { Step ramp is provided } \\
\text { wherever an accessible } \\
\text { route crosses a step or } \\
\text { kerb }\end{array}$ & NA & / & / \\
\hline 3 & SIGNAGE & & & \\
\hline a) & $\begin{array}{l}\text { The signage is clearly } \\
\text { seen by all people }\end{array}$ & / & / & / \\
\hline b) & $\begin{array}{l}\text { The signage is marked } \\
\text { with universal symbol }\end{array}$ & / & 1 & / \\
\hline a) & $\begin{array}{l}\text { Tactile floor located } \\
\text { atleast } 400 \mathrm{~mm} \text { before } \\
\text { the step }\end{array}$ & NA & NA & NA \\
\hline
\end{tabular}

Table 2 Observation result regarding disabled facilities in selected hospital (cont'd) 


\begin{tabular}{|c|c|c|c|c|}
\hline 4 & ENTRANCE & HRPB & HSM & HKK \\
\hline a) & $\begin{array}{l}\text { The entrance is free from } \\
\text { any obstructions }\end{array}$ & l & l & l \\
\hline b) & $\begin{array}{l}\text { The entrance accessible } \\
\text { with pathways }\end{array}$ & / & l & l \\
\hline c) & $\begin{array}{l}\text { The entrance are } \\
\text { provided with tactile } \\
\text { floor for blind people }\end{array}$ & $\mathrm{X}$ & $\mathrm{X}$ & $\mathrm{X}$ \\
\hline 5 & \multicolumn{4}{|l|}{ PATHWAYS } \\
\hline a) & $\begin{array}{l}\text { The pathways are free } \\
\text { from any obstructions }\end{array}$ & / & l & l \\
\hline b) & $\begin{array}{l}\text { The pathways are is at } \\
\text { least } 900 \mathrm{~mm} \text { wide }\end{array}$ & / & l & l \\
\hline c) & $\begin{array}{l}\text { The pathways are } \\
\text { provided with tactile } \\
\text { floor for blind people }\end{array}$ & $\mathrm{X}$ & $\mathrm{X}$ & $\mathrm{X}$ \\
\hline 6 & \multicolumn{4}{|l|}{ PARKING } \\
\hline a) & $\begin{array}{l}\text { The parking area is free } \\
\text { from any obstructions }\end{array}$ & / & l & / \\
\hline b) & $\begin{array}{l}\text { The parking area is } \\
\text { marked with universal } \\
\text { symbol }\end{array}$ & 1 & NA & / \\
\hline c) & $\begin{array}{l}\text { The parking space } \\
\text { located near to the } \\
\text { entrance }\end{array}$ & / & NA & l \\
\hline d) & $\begin{array}{l}\text { The parking space at } \\
\text { least } 3600 \mathrm{~mm} \text { wide }\end{array}$ & / & NA & / \\
\hline 7 & \multicolumn{4}{|l|}{ ELEVATORS } \\
\hline a) & $\begin{array}{l}\text { The button is accessible } \\
\text { for wheelchair user }\end{array}$ & l & $\mathrm{X}$ & $\mathrm{X}$ \\
\hline b) & $\begin{array}{l}\text { Braille code and voice } \\
\text { projection for visually } \\
\text { impaired people }\end{array}$ & l & $\mathrm{X}$ & $\mathrm{X}$ \\
\hline c) & $\begin{array}{l}\text { The space is accessible } \\
\text { for wheelchair user }\end{array}$ & / & / & l \\
\hline d) & $\begin{array}{l}\text { Handrails provided in the } \\
\text { elevator }\end{array}$ & l & / & $\mathrm{X}$ \\
\hline e) & $\begin{array}{l}\text { The door should not less } \\
\text { than } 900 \mathrm{~mm} \text { wide }\end{array}$ & l & l & / \\
\hline 8 & \multicolumn{4}{|l|}{ TOILET } \\
\hline a) & $\begin{array}{l}\text { The toilet is separated for } \\
\text { PWDs }\end{array}$ & l & l & l \\
\hline b) & $\begin{array}{l}\text { The door is accessible } \\
\text { for wheelchair user } \\
\text { should not less than } \\
\text { 900mm wide }\end{array}$ & l & $\mathrm{X}$ & / \\
\hline c) & $\begin{array}{l}\text { The area of the toilet is } \\
\text { big enough to fit the } \\
\text { wheelchair }\end{array}$ & I & 1 & I \\
\hline d) & $\begin{array}{l}\text { Handrails provided } \\
\text { should be at } 800 \mathrm{~mm} \text { high } \\
\text { from the floor and } \\
\text { adjustable }\end{array}$ & NA & $X$ & 1 \\
\hline e) & $\begin{array}{l}\text { The floor should not be } \\
\text { slippery }\end{array}$ & I & 1 & 1 \\
\hline f) & $\begin{array}{l}\text { Other facilities should be } \\
\text { accessible }\end{array}$ & 1 & 1 & $\mathrm{X}$ \\
\hline
\end{tabular}

Note: / - Yes, X- No, NA- Not Available

\subsection{Staircase}

The staircase is also one of the crucial facilities as it will be used by the disabled people to travel from one level to another. Hence, these facilities need to be disabled friendly as it will ease the movement of all categories of people. Based on the observation, even though staircase that provided at Hospital Kuala Kangsar did not have handrails at their both side, it still complies with the requirements as the other side of the stair is a wall. By referring to those three hospitals, none of them are provided with the tactile floor that to inform the visually impaired people regarding the floor or the staircase.

\subsection{Ramp}

Another medium of access that usually will be used by the disabled people is a ramp. Ramp will be used by physically impaired people and visually impaired people. Ramp can ease the movement of PWD especially those on a wheelchair. According to Malaysian Standard MS 1184: 2002, the ramp must be not less than $1200 \mathrm{~mm}$ width and landing area at every $6000 \mathrm{~mm}$. This requirement has been fulfilled by the ramp provided at Hospital Kuala Kangsar and Hospital Seri Manjung.

\subsection{Signage}

Based on the technical visit, all signage on disabled facilities is visible, clear, simple, and easy to read and understand by all people. This features already fulfilled the requirements by the standard requirements by Malaysian Standard. Besides, the symbol used by all the signage is a universal symbol. Also, the location of the signage also at the appropriate area and not hidden from the sight.

\subsection{Entrance}

According to MS1331:2003, the entrance of the building must be free from any obstacles and must be easily accessible by everybody especially disabled people. Based on the observation, all the three hospitals followed this requirement. Besides, the entrance also connected with the pathway that leads to the entrance. Also, none of the hospitals provide the tactile floor for visually impaired people. The tactile floor is one of the requirements that hospital does not comply with.

\subsection{Pathway}

The pathway is one of the media of travelling from one place to another. Because of that, the pathway must sizeable and free from any obstruction according to the standard requirements. All three (3) hospitals have pathway with more than $900 \mathrm{~mm}$ width as it will ease the movement of people and patient. Besides, the pathway also can accommodate up to two (2) numbers of a wheelchair at one time and the tiles also not slippery. However, there is no tactile floor provided especially for visually impaired people.

\subsection{Parking}

It is a requirement to provide parking space for disabled people as stated in the standard requirement that has been 
used worldwide. This requirement is important as disabled people must have a special privilege to access to the public building. According to MS 1184:2002, American with Disabilities Act 2010, Australian Standard and others, the minimum space for disabled parking should not be less that $3600 \mathrm{~mm}$ width as space for wheelchair movement. Base on the observation, only Hospital Raja Permaisuri Bainun and Hospital Kuala Kangsar that comply with the requirement as no disabled parking space provided at Hospital Seri Manjung. However, in Hospital Seri Manjung, drop-off point area are provided. Both parking space located near with the entrance as required by the standard requirements and marked with a universal sign.

\subsection{Elevators}

All hospital fulfils the requirements by providing elevators at the hospital. However, some of them did not fulfil the requirements that come with the elevator. For example, there are no handrails provided for elevators at Hospital Kuala Kangsar, and there is also no button with braille code for visually impaired people. Hospital Seri Manjung face the same issue. However, elevator at Hospital Raja Permaisuri Bainun nearly fulfilled all the requirements, but there is no provision of voice code for hearing impaired person. However, the braille code is provided.

\subsection{Toilet}

Observation found that those three hospitals provide the special toilet for disabled people at the hospital area. However, there are still some improvements that need to be done by the hospital management as the facilities provided not fully comply with the standard requirements. The disabled toilet at Hospital Raja Permaisuri Bainun has no provision of any handrails. It will cause difficulty especially to wheelchair user. Besides, the height of the sink and the mirror also not an appropriate for physical impairment people. Similarly, the disabled toilet provided at Hospital Kuala Kangsar also not fully complies with the standard requirements by the authorities. The handrail is located far from the toilet bowl and will cause difficulty to the user.

\section{Awareness towards Disabled Facilities in Public Hospital}

This section consists of seven main variables and other sub-questions that need to be rated by the respondents. This section is to determine the level of awareness of public towards the provision of the disabled facilities in public hospital. Hence, the respondents need to answer the question according to the listed facilities; entrance, toilet, parking, pathways, elevators, staircase and signage. This section is using Likert Scale to measure the level of awareness by circling on number 1 to 5 starting from "strongly not aware", "not aware", "moderate", "aware" and "strongly aware".

\subsection{Entrance}

Entrance is the main access that will be used by people to enter the building especially public hospital. The provision of proper entrance also been stated in Malaysian Standard 1184:2002 to ensure that disabled people can access into the public building without any limitation. The entrance must be accessible, free from obstructions and close proximity with disabled parking.

\section{a) Accessible main entrance}

According to Table 3, it is stated that the majority of the respondents aware that the entrance at public hospital is accessible to all people especially the one with disability, represent 4.10 mean value. However, there is still a $3 \%$ of respondents that "not aware" on this facilities.

b) Clear and ample space for entrance

It is important for entrance to be free from any obstructions as it will ease the movement of people into the hospital. Hence, according to Table 3 , it is stated mean value 4.10 . The least score is $3 \%$ of the respondents "not aware" whether the entrance is free from any obstruction or not.

\section{c) Assessable disabled parking}

For this factor, we can see that the majority of the respondents are aware that the entrance of the hospital located near with disabled parking. However, $30 \%$ of respondents not really aware by answering moderate and $8 \%$ (mean value 3.69) of respondents "not aware" and $1 \%$ is "totally not aware" with this situation. Basically, this is happened due to lack of awareness of disabled facilities by public.

\subsection{Toilet}

Toilet for disabled people must be located separately as it has its requirements that need to be followed.

\section{a) Separated toilet for disabled person}

Table 3 highlighted that mean value is 4.06 , therefore most respondents are "aware" that there is a separated toilet provided for disabled people in the hospital. This indicates that most of the public are "aware" with the disabled toilet and this is also another indicator to show that most of the hospital provides separated toilet for disabled people.

\section{b) Accessible toilet space for wheelchair user}

Even though there is a separated toilet provided for disabled people, but the space of the toilet also must be accessible by a wheelchair user. Mean value score is 4.06 show that respondents are "aware" that the space of the disabled toilet provided at the hospital is accessible by the wheelchair user. 


\section{c) Additional facilities}

Additional facilities also need to be provided in the disabled toilet for the usage of the disabled person and also as an assistant for them to move in the toilet. Mean value of 3.93 resulted that the awareness level is good

\subsection{Parking}

Disabled parking is one of the important facilities as it will give enough space for disabled people especially those with a wheelchair to transfer from their vehicle to the wheelchair. Besides, the parking space must be located near with entrance as it will ease the movement of disabled people.

\section{a) Accessible parking location}

Majority of the respondents are "aware" that the location of the disabled parking is near with the entrance. This statement is supported by mean value 3.75 . This is a good indicator as it shows that the disabled parking is provided and near with the entrance to ease the movement of the disabled people.

b) Ample parking space and free from obstructions

From the result, mean value of 3.72 shows the parking is free from any obstructions that can limit the access of the disabled people towards the parking space.

\section{c) Clearly provided disabled signage}

The score of mean value 4.00 represent that majority of the respondents are "aware" with the situation and realise the existence of the signage.

\subsection{Pathways}

Pathways will be used by all people especially pedestrian with PWD who are also using the pathways to go to another place. Therefore, the pathways provided needs to be disabled-friendly to ease the movement of disabled people.

\section{a) Provision of tactile floor for visually impaired people}

Mean value of 2.74 shows the low level of awareness towards the facilities. This is happened because most of the pathways at the hospitals are not provided with a tactile floor. Hence, that reason can contribute to the low level of awareness on this facility.

\section{b) Free from obstructions pathways}

Awareness is happening represent by mean value of 3.90 , that the pathway at the public hospital is free from obstructions. It is important for the pathway to be free from any obstruction that can limit the movement of the people especially disabled people from entering the building. c) Pathways location

Basically, the parking space will be located a bit far from the entrance and people tend to use pathways to go to the entrance. Hence, it is crucial to ensure that the pathways will straight lead to entrance as it can help disabled people access into the hospital. Mean value of 4.10 show respondents are aware that hospital's pathways are lead to the entrance

\subsection{Elevators}

Elevators need to be provided by the hospital as a medium of transporting people from one level to another despite specific categories of people. The elevators need to be provided with an appropriate space for wheelchair to fit in and other facilities that are disabled friendly.

\section{a) Elevators with handrails}

Based on Table 3, mean value score is 3.91 show more than half of the respondents are aware that the public hospitals' are providing handrails in the elevators This result is a good indicator that the elevators of the hospitals are complying with one of the Malaysian Standard's requirement.

\section{b) Accessible space for wheelchair user}

Elevators is used by disabled people especially those with physically impaired and wheelchair user as their condition are limited. The result shows mean value of 4.03 where respondents are aware that elevators in public hospitals are accessible for wheelchair. This is proved that elevators users in a public hospital are physically suitable for impaired user.

c) Elevator with easily accessed button

The result shows that mean value of 3.96. Therefore, respondents are aware that the button provided at the elevators can be accessed by disabled person. Even though not all the requirements fulfilled, but the button still can be accessed by disabled people.

\subsection{Staircase}

Staircase is one of the facilities that majorly used by the people in the hospitals. Hence, the staircase needs to be barrier-free and constructed according to the requirements that provided in Malaysian Standard MS1184:2002.

\section{a) Clear from obstructions for staircase}

Table 2 shows mean value of 3.97. The respondents are aware that the staircase at the public hospital is free from any obstructions that can limit the movement of disabled people.

b) Continuous handrails for staircase 
Mean value of 4.16 show that high awareness of respondents of this item. The staircase at the public hospitals is provided with continuous handrails for the use of the public and disabled people. From the observation, it was found that some of the staircases at the public hospitals are not provided with handrails at both sides since the staircases are attached with the wall.

c) Staircase steps with tactile floor

Table 3 highlights that mean value of 3.96 represent that least respondents are aware with the provision of tactile floor at the staircase for the usage of visually impaired people. This result is due to the no provision of the tactile floor at the staircase area as the medium of information towards the visually impaired people. This shows that there is a few numbers of hospitals that comply with the requirements of providing tactile floor at the staircase for disabled people.

\subsection{Signage}

Signage is important to convey a message to the people by showing the symbol and statement. Besides, signage helps people in acknowledging the places or facilities that specially provided for some people especially disabled facilities. Besides, the signage provided to assure all people received and understand the message that need to be conveyed.

\section{a) The existence of the disabled signage}

Mean value of 4.03 shows that most respondents are aware that there is an existence of the disabled signage on every disabled facility provided. From the result, it shows that the signage that provided by the hospital is clearly seen and acknowledged by the public.

\section{b) Understanding of the signage}

Under the implementation of Malaysian Standard, all of the disabled signage must be marked with international symbol of disabled people to ensure that all people are well aware of the disabled facilities provided. Majority of the respondents are well aware that the signage provided at public hospitals is easy to understand (mean value of 4.08).

\section{c) Location of the signage}

The location of the signage also need to be located at an appropriate area as it will be an indicator to the user and public about the disabled facilities provided. Besides, it is also as information to public that space or facility is specially provided for disabled people. Mean value of 4.00 was good indicator that the location of the disabled signage is at an appropriate area.
Table 3: Summary on the level of awareness of the public towards disabled facilities in public hospital

\begin{tabular}{|l|l|c|}
\hline Item & Description & Mean \\
\hline 1 & Continuous handrails for staircase & 4.16 \\
\hline 2 & Assessable main entrance & 4.10 \\
\hline 3 & Clear and ample space for entrance & 4.10 \\
\hline 4 & Understanding the signage & 4.08 \\
\hline 5 & Separated toilet for disabled person & 4.06 \\
\hline 6 & Accessible toilet for wheelchair user & 4.06 \\
\hline 7 & The existence of disable signage & 4.03 \\
\hline 8 & Accessible space for wheelchair user & 4.03 \\
\hline 9 & Pathways location & 4.01 \\
\hline 10 & Clearly provided disable signage & 4.00 \\
\hline 11 & Clear form obstruction for staircase & 3.97 \\
\hline 12 & Elevator with easily accessed button & 3.96 \\
\hline 13 & Additional facilities at disabled toilet & 3.93 \\
\hline 14 & Elevators with handrails & 3.91 \\
\hline 15 & Free from obstacles pathways & 3.90 \\
\hline 16 & Accessible parking location & 3.75 \\
\hline 17 & $\begin{array}{l}\text { Ample parking space and free from } \\
\text { obstructions }\end{array}$ & 3.72 \\
\hline 18 & Accessible disable parking & 3.69 \\
\hline 19 & Staircase steps with tactile floor & 2.96 \\
\hline 20 & $\begin{array}{l}\text { Provision of tactile floor for visually impaired } \\
\text { people }\end{array}$ & 2.74 \\
\hline
\end{tabular}

Note: 0.00-1.00 Totally not aware, 1.00-2.00 Not aware, 2.00-

3.00 Moderate, 3.00-4.00 Aware, 4.00-5.00 Absolutely aware

Based on Table 3, most of the listed items scored the mean value above 3.00 , which indicate that the respondents aware with facilities provided. The highest mean scored by staircase, entrance, signage and toilet. These items are most important for PWD in hospital. However, only two items score mean value below 3.00. There are, tactile floor for staircase and for pathways. Therefore, provision of tactile floor for visually impaired people at pathways is less aware by the public with moderate ranking. As mentioned before, not all the pathways at the public hospital are provided with the tactile floor and there are several of the respondents that did not have any idea on what the tactile floor is, so this situation can contribute to the low numbers of respondents that aware with this facility.

\section{Summary and Conclusion}

From the result that have been analysed, most of the respondents were "aware" with all the disabled facilities provided at the hospital. However, from the observation, it was found that most of the requirements are fulfilled, but there is still room for improvement needed for all of the disabled facilities for better effects in future. The result presented that these three hospitals design had follow UBBL standard in general. It was found that there are five factors that are considered as major factors can be improvement the disabled facilities in the public hospitals. The factors are construction stage, government responsibility, quality, people's perception and maintenance. Facilities for PWD need to be maintained to prolong the usage. At the construction stage, government 
need to enforce straight regulation on using UBBL not as guidelines alone but need to comply. People perceptions also one of the issue that need to be catered, so that the facilities provided for PWD is not being misused. Table 4 shows the summary of the factors in enhancing the disabled facilities in public hospital.

Table 4: Summary of factors in enhancing the disabled facilities in public hospital

\begin{tabular}{|c|c|}
\hline Factors & Reason \\
\hline Maintenance & $\begin{array}{l}\text { The disabled facilities need to } \\
\text { undergo periodic inspection and } \\
\text { maintenance in order to ensure that } \\
\text { all the disabled facilities are well- } \\
\text { functioning and the quality of the } \\
\text { disabled facilities can be maintained. }\end{array}$ \\
\hline $\begin{array}{l}\text { Construction } \\
\text { stage }\end{array}$ & $\begin{array}{l}\text { All the disabled facilities need to be } \\
\text { vetted from the beginning which is } \\
\text { since the construction stage to ensure } \\
\text { that all the facilities are provided } \\
\text { accordance with the requirements. }\end{array}$ \\
\hline Government & $\begin{array}{l}\text { The government also needs to play } \\
\text { their own roles in assuring that all the } \\
\text { public building can be accessed by } \\
\text { the disabled people and the facilities } \\
\text { are disabled friendly. }\end{array}$ \\
\hline Quality & $\begin{array}{l}\text { More barrier-free facilities need to be } \\
\text { provided especially in public building } \\
\text { like hospital in order to avoid any } \\
\text { limitation occurred to disabled } \\
\text { people. }\end{array}$ \\
\hline $\begin{array}{l}\text { People's } \\
\text { perception }\end{array}$ & $\begin{array}{l}\text { All people are responsible to ensure } \\
\text { that all the disabled facilities are in } \\
\text { good condition and never been } \\
\text { abused by uncivilized people. }\end{array}$ \\
\hline
\end{tabular}

\section{References}

1. Abdul Rahim, A. (2011). Application of Universal Design Towards World Class Cities.

2. Abdul Talib Y, Rajagopalan P and Yang R. J. (2013). " Evaluation of building performance for strategic facilities management in healthcare." Facilities. 31(13/14): 681-701.

3. Creswell, J. (2014). Research Design. 4th ed. [S.1.]: Sage Publications.

4. Ibrahim, Z. (2011). Most Handicapped People Not Yet Registered With JKM. Inclusive Design for Malaysia. http://inclusivedesign.wordpress.com

5. Imrie, R. (2012). Universalism, universal design and equitable access to the built environment. Disabil Rehabil, 34(10), pp.873-882.

6. Islam, M. (2014). Rights of the People with Disabilities and Social Exclusion in Malaysia. International Journal of Social Science and Humanity, 5(2), pp. 171-177.

7. Kadir, S., Jamaludin, M. and Rahim, A. (2012). Building Managersâ€TM Perception in Regards to Accessibility and Universal Design Implementation in Public Buildings: Putrajaya case studies. Procedia - Social and Behavioral Sciences, 35, pp.129-136.

8. Lingan, L. (2012). More Boarding Facilities Needed. Business Times, [online] p.1. http://www.nst.com.my

9. Morris, J. (2001). Impairment and Disability: Constructing an Ethics of Care That Promotes Human Rights. Hypatia, 16(4), pp.1-16.

10. News Straits Times, (2014). Making Life Easier for Disabled. [online] p.1. http://www.nst.com.my

11. Verea-Hernando, H., Valdés-Cuadrado, L., LópezCampos, J., Fandiño-Orgeira, J. and Blanco-Ramos, M. (2011). Coordination Between a District Hospital and a Reference Hospital: Evaluation of Chest Disease Care Models. Archivos de Bronconeumología (English Edition), 47(6), pp.290-295.

12. Wall, L. (2007). Where should obstetric vesicovaginal fistulas be repaired: At the district general hospital or a specialized fistula center? International Journal of Gynecology \& Obstetrics, 99, pp.S28-S31.

13. Wilson, M. and Scior, K. (2013). Attitudes towards individuals with disabilities as measured by the Implicit Association Test: A literature review. Research in developmental disabilities, 35(2), pp.294--321. 